\title{
Essential Tools to Establish a Comprehensive Drought Management Plan - Konya Basin Case Study
}

\author{
Mustafa Berk DUYGU'ㄹ, Bilal KİRMENCİĞLU', \\ Maruf ARAS ${ }^{1}$
}

\begin{abstract}
Drought is a vital phenomenon in semi-arid regions; particularly in closed basins where water resources are scarce to meet demands. Konya Basin of Turkey is a closed basin which is susceptible to droughts at the ultimate level. In order to estimate drought risks and establish necessary measures against drought events, a Drought Management Plans is prepared for this basin. This study is aimed to share experiences achieved during the preparation of this plan and discuss essential tools to establish a comprehensive drought management plan. Preparation of a drought management plan includes, determination of prospective drought risks, climate change analyses, assessment of water budget, vulnerability assessment and essential measures to be taken at pre-drought, during drought and post drought stages.
\end{abstract}

Key words: drought, drought analyses, climate change, water scarcity, mitigation

\section{Introduction}

Droughts occur as a result of natural (climatological) processes and it can affect specific areas for specific time intervals. Although, drought is a natural disaster, such as floods and earthquakes, it has a much longer onset and effecting period. The duration of a significant drought event can be expressed in terms of years. Drought emerges slowly but the consequences it causes can be serious and costly. In order to mitigate the impacts of droughts, drought vulnerability of the affected region must be very well assessed.

Turkey has been quite often exposed to the effects of this natural disaster. Although, spatio-temporal analyses are not sufficient for earlier droughts, it has been known that the serious droughts occurred in 1804, 1876 and 1928 caused loss of agricultural products and livestock as well as the migration of desperate farmers. It is estimated that the drought event occurred in 1876 caused loss of 200.000 lives by causing famines and diseases. In the republic era, in 1928, 1973, 1989, 1990, 1993, 1998-2001, 2008 and 2013, serious droughts were also observed (Yağc1, 2007).

Especially for the Mediterranean countries, adverse effects of the global climate change are observed and drought is becoming a serious problem. Mediterranean countries such as Turkey are expected to observe temperature increases and precipitation deficiencies in near future which may increase severity and frequency of drought events (IPCC, 2014).

\footnotetext{
${ }^{1}$ Ministry of Forestry and Water Affairs, General Directorate of Water Management, 06510, Yenimahalle-Ankara Turkey mbduygu@ormansu.gov.tr1,bkirmencioglu@ormansu.gov.tr2,marufaras@ormansu.gov.tr ${ }^{3}$
} 
Having limited amount of water resources and vast agricultural land as well as being a closed basin make Konya Basin where the most vulnerable area of Turkey against droughts. A drought Management Plan for this basin has been prepared to mitigate the negative impacts of possible droughts and keep water scarcity at the minimum level by determining measures to be taken before, during and after the drought periods (SYGM, 2015).

Drought risk assessment, climate change analyses, determination of water budget, sectorial vulnerability assessment are vital to prepare a comprehensive drought management plan. All these steps are the essential tools to determine the necessary measures at all stages of droughts and to prepare a drought management plan.

The purpose of this study is to discuss the essential of a drought management plan by addressing the experiences obtained from the preparation process of Konya Basin Drought Management Plan.

\section{Drought and Drought Management}

"Drought" means the naturally occurring phenomenon that exists when precipitation has been significantly below normal recorded levels, causing serious hydrological imbalances that adversely affect land resource production systems. (UNCCD, 1994).

An efficient drought mitigation can only be possible with an effective drought management which can be operated efficiently by a drought management plan. Drought management plans must include actions to be taken at pre-drought, during drought and post drought phases as well as the responsible actors who are responsible from taking these actions.

Drought management plans are the important elements of integrated water management of any water basin. In order to determine measures at all phases of a drought, meteorological, hydrological and agricultural drought characteristics, vulnerability of ground and surface waters against droughts, drought effects on different parties and water users, possible effects of global climate change on future droughts have to be considered while determining the measures in the drought management plan.

\section{Konya Basin}

Konya Basin is a closed basin, which is surrounded by Sakarya and Kiz1lırmak River Basins in the north, Kizılırmak and Seyhan River Basins in the east, Eastern Mediterranean Basin in the south and Antalya and Akarçay River Basins in the west. The basin is the third biggest basin among 25 basins in Turkey, and has a surface area of $50.073 \mathrm{~km}^{2}$. Most of the basin is covered with large plains having an altitude ranging between 900-1050 meters that constitutes the Central Anatolian Plateau. Since the basin is surrounded by high mountains, the basin does not have any other inputs than precipitation. The precipitation amount is more in the south and southwest of the basin in comparison with its north and east. The annual average precipitation height of the basin is $384 \mathrm{~mm}$. approximately $15 \%$ of the annual average precipitation creates surface runoff and constitutes the surface water resources of the basin. 
Konya Basin is one of the 25 river basins of Turkey. Konya Basin covers some of the areas of Aksaray, Ankara, Antalya, Isparta, Karaman, Konya, Mersin, Nevşehir and Niğde provinces (Figure 1.1.).

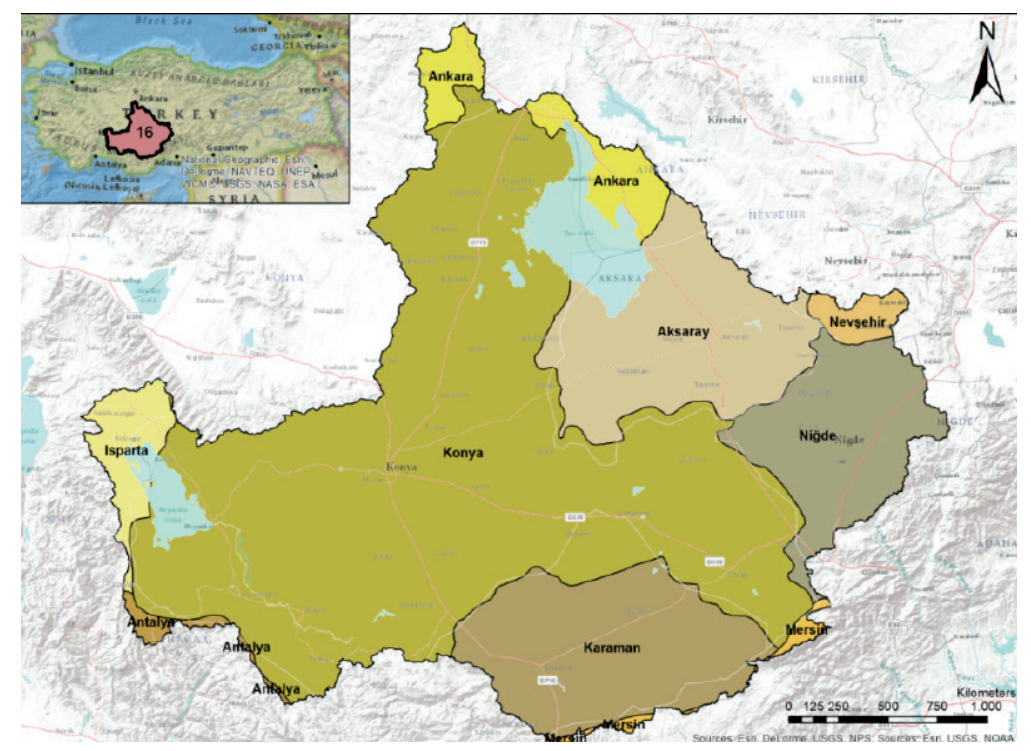

Figure 1.1. Konya Basin

\section{Method}

\section{Climate Modelling}

In order to estimate local effects of global climate change, downscaling approaches were developed which downscales the global estimates of climate into local scale (Wilby et al., 2002; Tripathi et al., 2006; Okkan \& Inan, 2014). There are two main downscaling methods in the literature namely dynamic and statistical downscaling (Wilby et al, 2002).

In this study, both of these methods were utilized together. For dynamic downscaling method, for both Konya Basin and Turkey, the most appropriate global circulation models were determined. The outputs of the climate model were statistically downscaled to meteorological observation stations. The differences between the outputs of dynamic and statistical downscaling were eliminated using appropriate methods (such as bias correction) and for further studies, the outputs of dynamic downscaling method was utilized.

The global models -MPI-ESM-MR, HadGEM2-ES and GFDL-ESM2M- used in the project are the general circulation models developed by Max Planck Meteorology Institute (Germany), Met-Office Hadley Centre (England) and NOAA Geophysical Fluid Dynamics Laboratory (USA), respectively. Those global models have been previously evaluated by centers developing Regional Climate Models, particularly by Abdus Salam International 
Theoretical Physics Center (ICTP), and are used within the scope of this project since they produce the accurate model results for the Mediterranean region.

\section{Drought Analyses}

Drought has been characterized for its meteorological, hydrological, agricultural, geographic and economic aspects and analyzed under different definitions. This characterization and definitions include the evaluation of many different drought variables and parameters as well as the possible adverse impacts of droughts. Extreme events occurred as a result of deficiency or excessiveness of variables such as precipitation, temperature, moisture, evaporation, transpiration and wind speed are taken into account in drought analyses (Türkeş, 1990).

Meteorological drought means the decrease in rainfall compared to long term averages for a certain duration. In order to determine meteorological droughts, different statistical methods and threshold values are used for different areas. For example, for a certain location, if the total of 21 days precipitation is below $1 / 3$ of normal levels or there is no rainfall for 15 days, the situation can be evaluated as meteorological drought. (Türkeş, 1990).

Hydrological drought is deficit of water in hydrological respect where decreases in surface and ground waters are taken as the basis of drought. Hydrological drought and its severity can be measured by water level measurements of water environments (such as rivers, lakes, reservoirs, groundwater, etc.). Because of the linear time dependent relation between precipitation deficiency and water deficit in lakes and reservoirs, hydrological drought is not one of first indicators of drought. Even after the end of meteorological droughts, hydrological drought may affect the region for a long period with certain lag times, depending on the physiographical conditions and soil characteristics of the region. (Türkeş, 1990)

Agricultural drought means the inadequacy of soil water in the root zone which hinders plant growth. Especially at the growth period where the plant is highly vulnerable to water deficiency, if the soil moisture is not adequate, agricultural drought occurs (Wilhite \& Glantz, 1985). Agricultural drought may occur just after meteorological droughts at rainfed agricultural areas, it may also occur as a result of hydrological drought at irrigated areas.

As drought severity, duration and vulnerability of communities increase, and if a drought risk management plan is either not available or not working properly, socio-economical drought may occur as a result of the consequences of meteorological, hydrological and agricultural droughts. (Wilhite \& Glantz, 1985)

In order to determine and classify the complicated process of droughts by means of their severity, duration and geographical distribution, several climatological, meteorological or hydrological drought indices appears in literature. Drought indices can identify the drought occurrence, evolution and severity in a very explicit manner. Each one of them has its own characteristics and in general similar indices produce similar results. Eight of the most common drought indices were utilized in this study (Table 2.1). 
Table 2.1.

Drought indices used in drought analyses and their field of study

\begin{tabular}{|c|c|c|c|c|c|c|c|c|c|}
\hline Index & 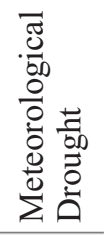 & 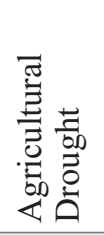 & 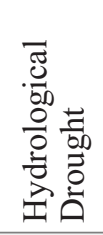 & 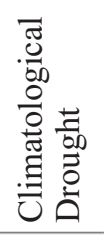 & 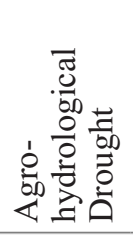 & 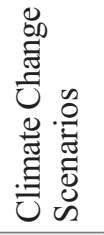 & 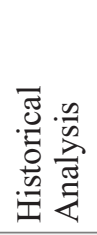 & 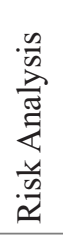 & 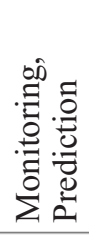 \\
\hline Percentage of Normal Precipitation (PNI) & * & * & & & & & & & \\
\hline Standardized Precipitation Index (SPI) & $*$ & & $*$ & & & & & & * \\
\hline Palmer Drought Severity Index (PDSI) & * & $*$ & & & & & * & $*$ & \\
\hline Palmer Hydrologic Drought Index (PDHI) & & & * & & & & & & * \\
\hline Palmer Moisture Anomaly Index (ZNDX) & & & & & * & & & & \\
\hline Aydeniz Index & & & & * & & & & & \\
\hline Erinç Drought Index (Im) & & * & & * & & $*$ & & & * \\
\hline Aridity Index (AI) & $*$ & $*$ & & * & & $*$ & & & * \\
\hline
\end{tabular}

\section{Modelling Water Budget}

Drought related changes in precipitation and temperatures hydrologically triggers the changes in streamflow. Therefore, significant changes in water potential is an expected result of droughts. Changing of water potential during droughts effect many water users and sectors including municipal water, agriculture and energy. Reservoirs which were planned and constructed in accordance with observed streamflow situations may not be operated efficiently under the conditions influenced by the climate change. Therefore, it is vital to estimate drought related changes and explain the uncertainty in the water budget. Otherwise, characteristics and dimensions of additional measures (such as new storages, interbasin water transfers, etc.) taken against the thread may not be appropriate enough. These inappropriateness, as a result, may cause waste of both natural and financial resources.

In this project, a regional analysis is performed by using three different global climate model outputs and dynamical and statistical downscale methods. The impacts of the changes in the hydro-meteorological parameters on streamflow are analyzed using parametric rainfall-runoff models. The water budget of the basin is determined by using internationally recognized parametric water budget models (HEC-HMS and Thronthwaite Monthly Water Balance Model). The models are operated with hydro-meteorological data created in monthly time-scale with annual periods for the years between 2015 and 2020 and with 5-year periods for the years between 2020 and 2050 and thusly future streamflow values are estimated.

The results obtained at this stage and the current situation surface and subsurface water resources are used in projecting water potential for future and calculating the water budget. 


\section{Results}

\section{Potential Effects of Climate Change on Konya Basin}

In order to assess the potential effects of global climate change on Konya Basin, climate modelling and projection has been made. The projections up to 2050 were considered for three different global circulation models and two different scenarios. The results suggest that the total precipitation has a decreasing trend between 6 to 15 percent and the average temperature has an increasing trend between 1 to $2.5^{\circ} \mathrm{C}$.

\section{Changes in average surface temperature}

The estimated surface temperature changes until 2050 in accordance with GFDL-ESM2M global circulation model and RCP 4.5 scenario are shown with respect to months in Figure 3.1. The results suggest that, especially for summer session, temperatures will increase around 1.5 to $2{ }^{\circ} \mathrm{C}$.
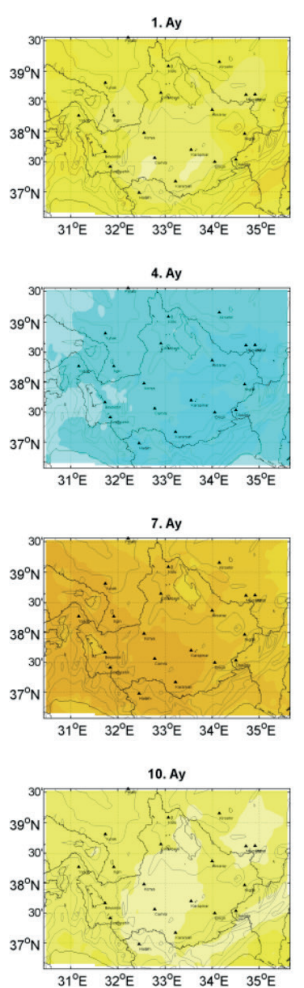

TEMP-GFDL-45-ERACOR-Proj:2015-2050-Ref:1980-2004

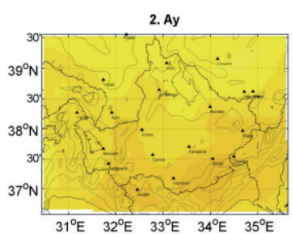

5. Ay
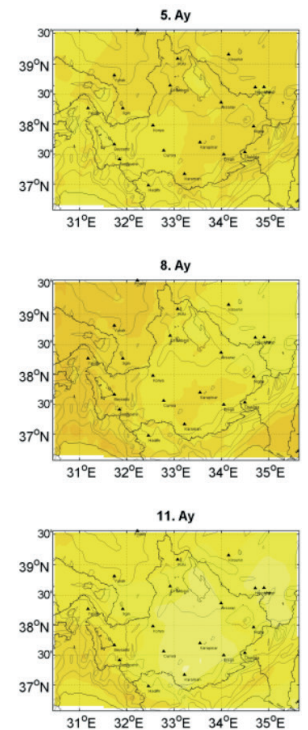
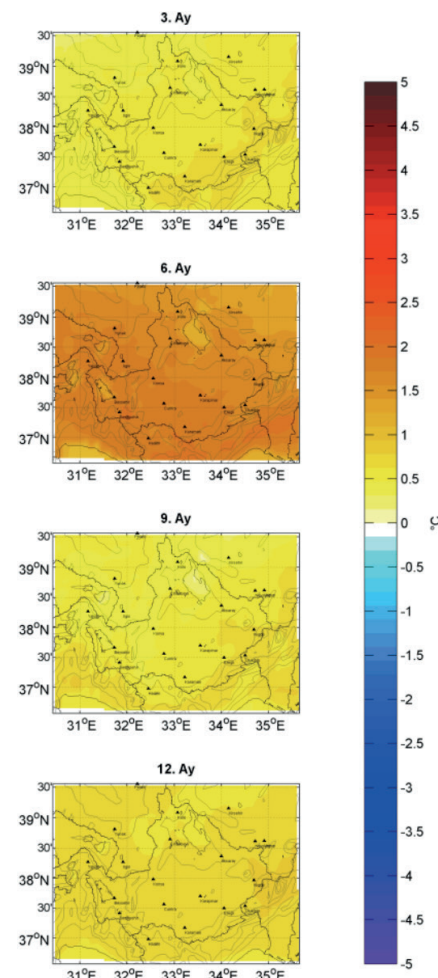

Figure 3.1. Expected changes in average surface temperature in Konya Basin in accordance with GFDL-ESM2M global circulation model and RCP 4.5 scenario. 


\section{Changes in precipitation}

Expected changes in the precipitation in accordance with three global circulation models and two different scenarios are shown in Figure 3.2.

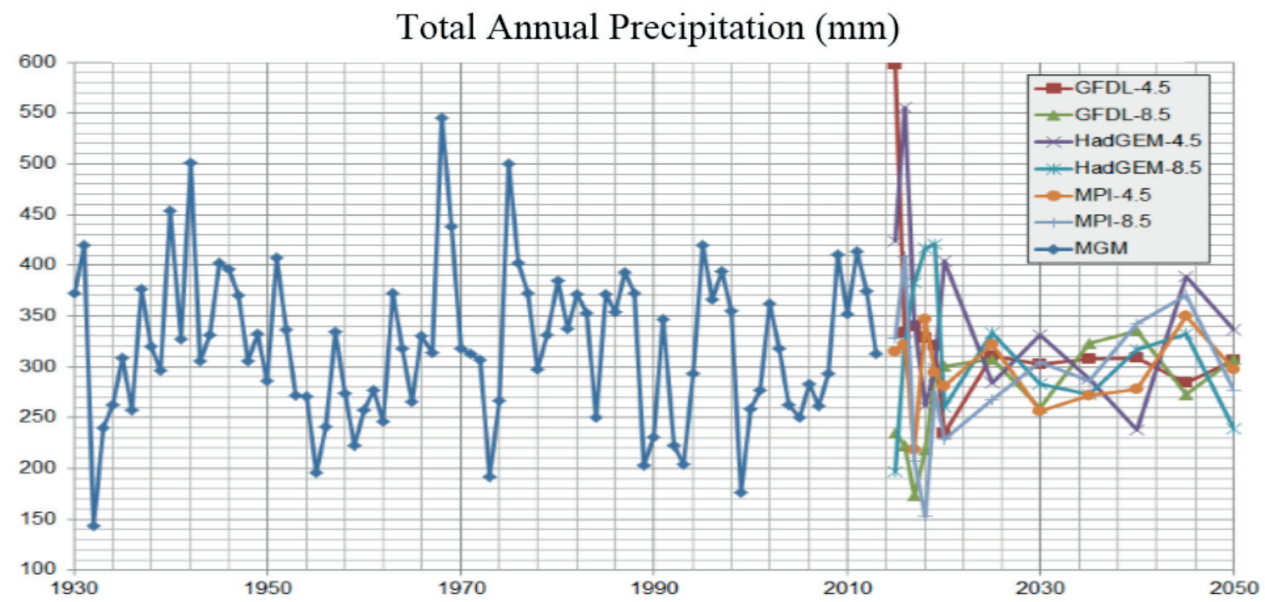

Figure 3.2. Expected changes in the precipitation in Konya Basin

The estimated winter precipitation changes until 2050 in accordance with HAD-GEM global circulation model and RCP 4.5 scenario are shown with respect to months in Figure 3.3. The main actor of the water budget of the Konya Basin is the winter precipitation which seems to have a decreasing trend according to the future projections.
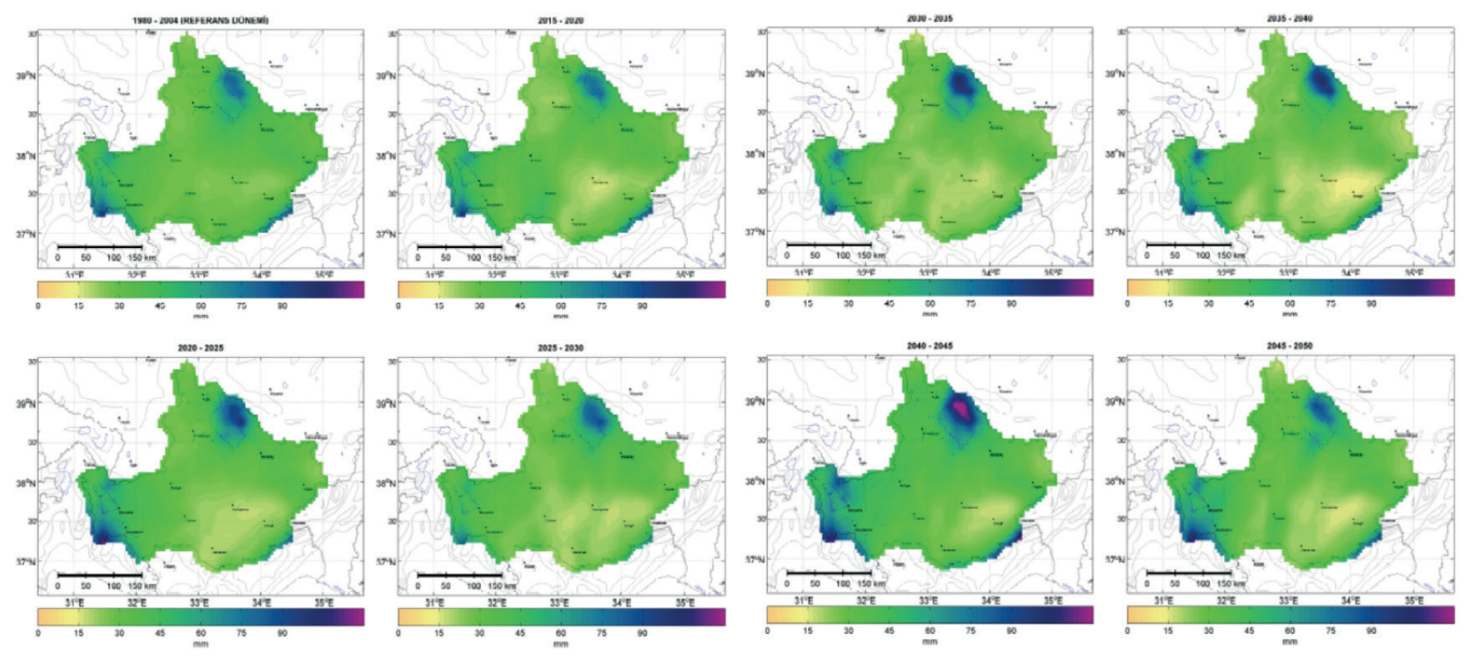

Figure 3.3. Expected winter precipitation changes in Konya Basin in accordance with GFDL-ESM2M global circulation model and RCP 4.5 scenario. 


\section{Drought Analyses of Konya Basin}

Past drought events of Konya Basin were determined as it was mentioned in Section 2.2 by using 19 meteorological observation stations' long term data by using several drought indices. The results of all indices were used to determine common drought periods of the basin. The results indicate that 1972-1974, 1984-1985, 2000-2001, 2004-2005, 2004-2008 and 2013 are the common drought periods of Konya Basin. Spatial distribution of drought periods whic were determined using PDSI are shown in Figure 3.4.

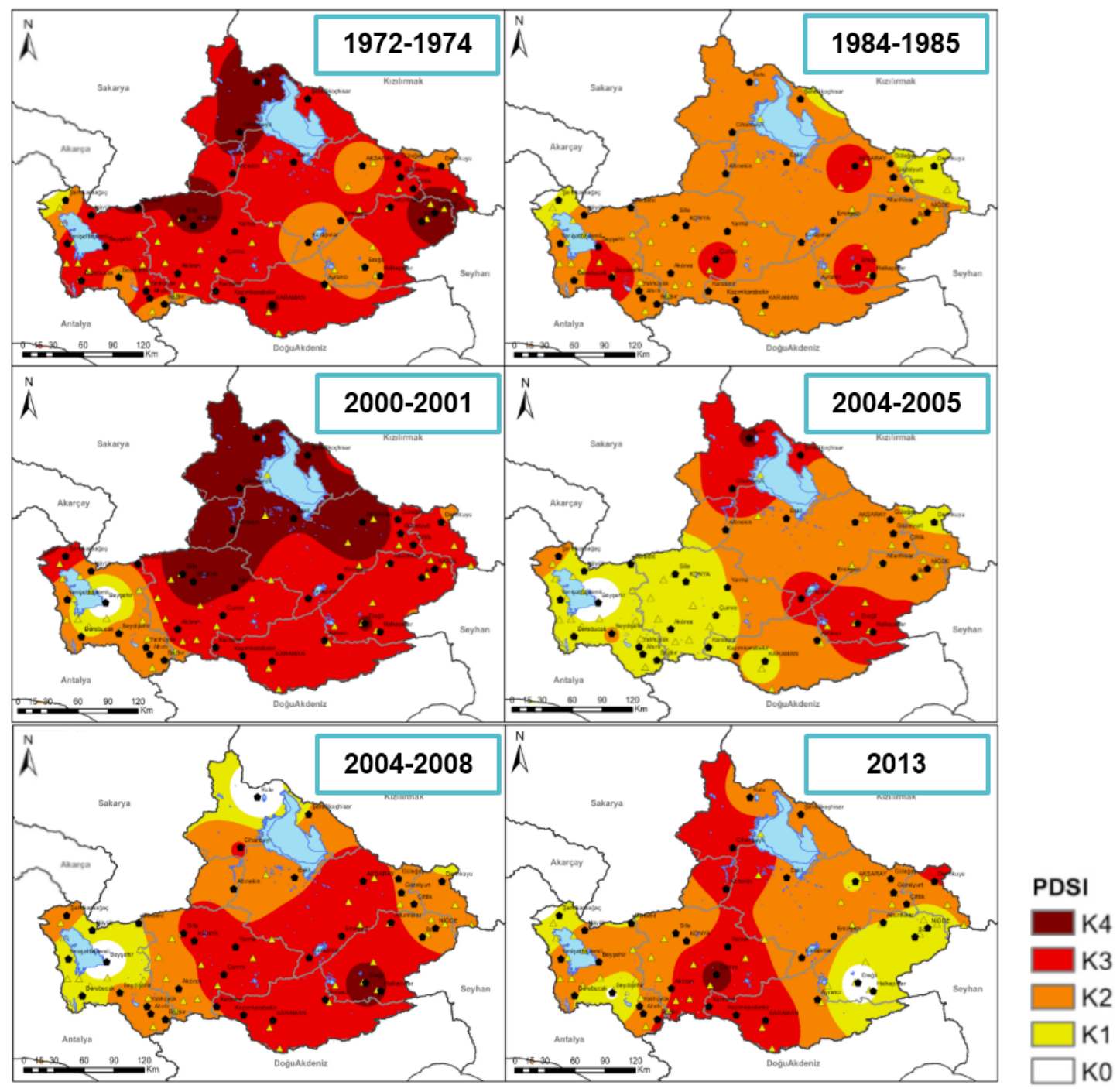

Figure 3.4. Common drought periods of Konya Basin (PDSI) 
The results obtained from climate modelling study (Section 2.1) were used in calculating drought indices (Section 2.2) and potential future droughts were estimated. The results suggest that probability of occurrence of extreme droughts may increase around $12 \%$ to $46 \%$ until the year 2050 .

\section{Determination of Changes in the Water Budget of Konya Basin}

Groundwater and surface water potentials of the basin were calculated using annual precipitation data recorded at 1974-2013 period. The utilizable water potential of Konya Basin is assessed as $4.679 \mathrm{hm}^{3} /$ year. $57.2 \%\left(2.676 \mathrm{hm}^{3} /\right.$ year $)$ of the potential is surface water resources and $42.8 \%\left(2.003 \mathrm{hm}^{3} /\right.$ year $)$ of the potential is groundwater resources. The water balance diagram of the basin is shown in Figure 3.5.

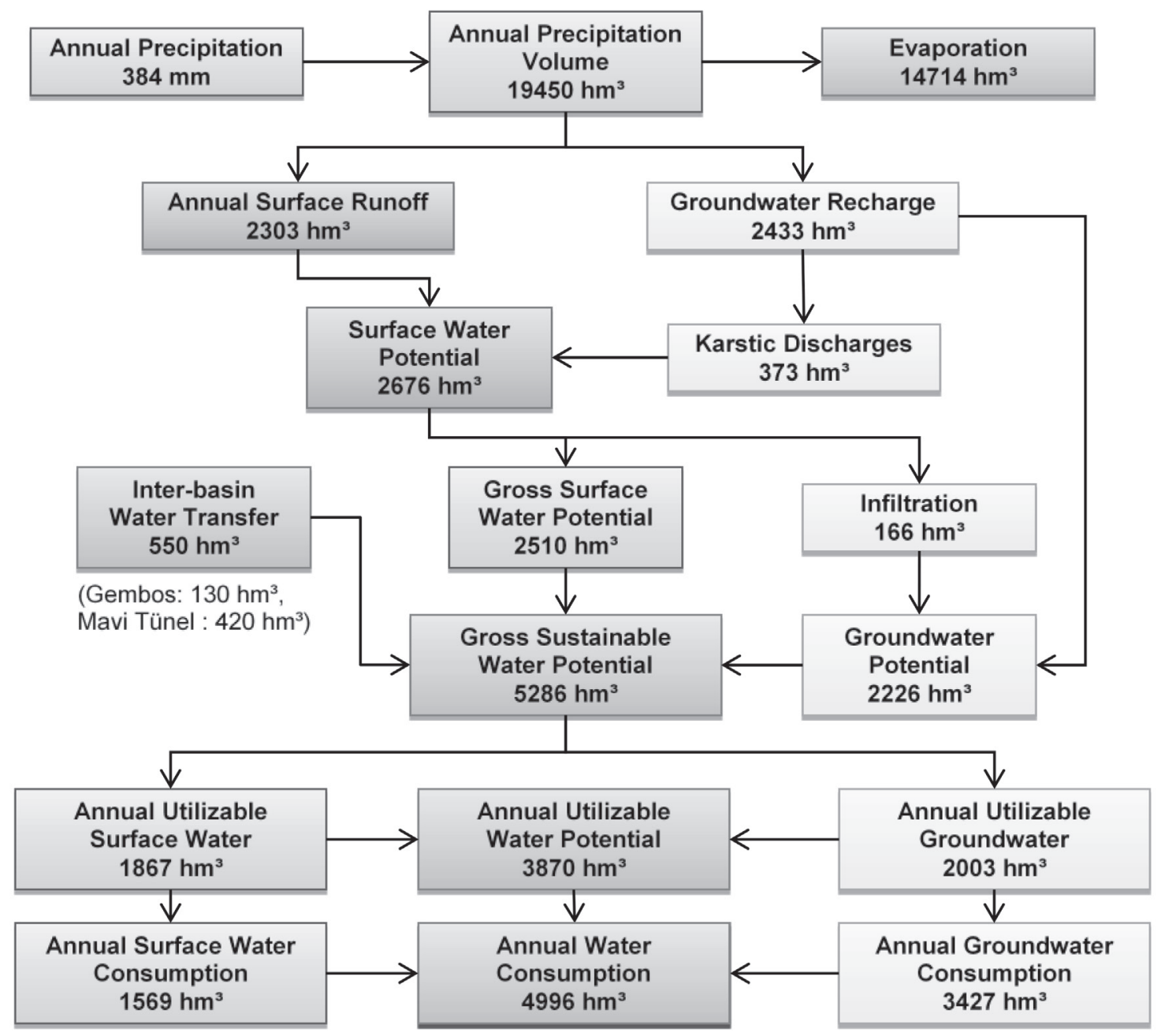

Figure 3.5. Konya Basin water balance diagram 
Before starting the hydrological studies, climatologic outputs of HadGEM2-ES model (Section 2.1) with RCP 4.5 and RCP 8.5 scenarios were corrected with the ground data of the meteorological observation network and Era-Interim data. Potential changes in the water potential of Konya Basin as a result of the expected changes, obtained as the output of the climate model HadGEM2-ES (Section 2.1), are presented in Figure 3.6 and Figure 3.7. The figures are depicted as box-and-whisker plots to summarize large number of qualitative data. In those figures, the upper and lower lines show the maximum and minimum values, respectively, the lower box shows the median and the first quarter, and the upper box shows the median and third quarter, while the black points show the mean and the black dashed line shows the interannual variations of mean values. Significant decreasing trends were observed for both surface water (Figure 3.6) and groundwater potentials (Figure 3.7) for the years 2035 and 2040.

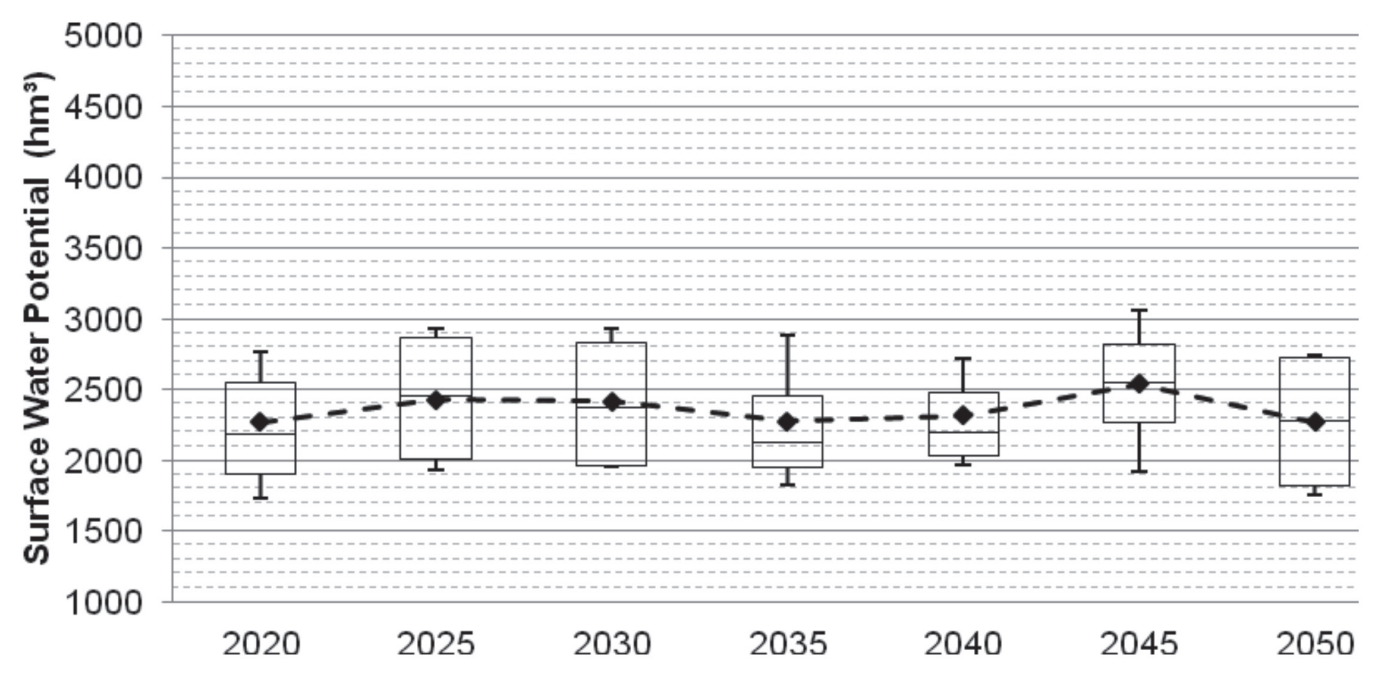

Figure 3.6. Expected changes in surface water potential of Konya Basin (2020-2050)

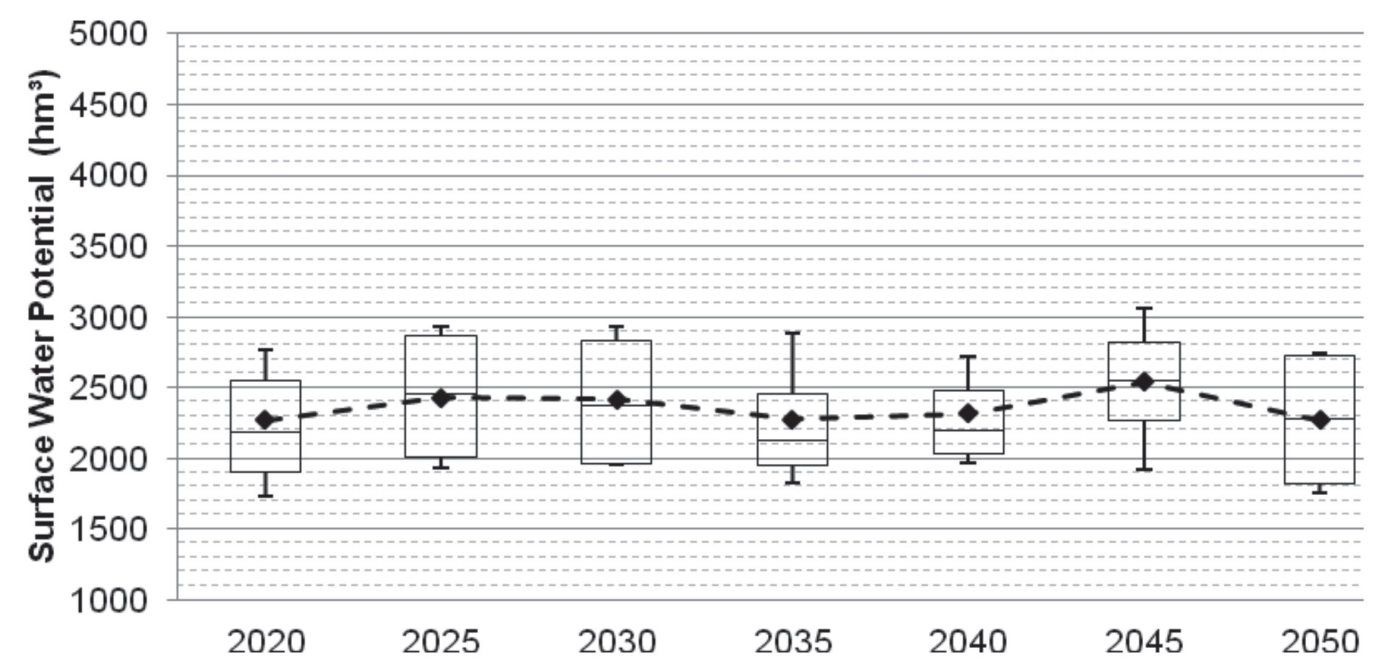

Figure 3.7. Expected changes in groundwater potential of Konya Basin (2020-2050) 


\section{Drought Vulnerability Analyses}

Vulnerability (sensitivity, susceptibility) assessment is an innovative analysis method, which has been developed to create a bridge for the determination of measures using the results of the impact assessment by focusing the attention of the decision makers on the reasons creating the vulnerability instead of the analysis of negative impacts that may occur as the result of a triggering event such as drought (natural disaster).

The basic components of vulnerability assessment are: the thread created by drought on the inspected region, the sensitivity of the region to drought, potential impacts based on experiences, and the adaptation capacity of the region to the drought conditions.

For four main sectors in Konya Basin (Agriculture, municipal water, industry and ecosystem) sectoral vulnerability assessments were conducted.

Required water is supplied from surface or groundwater resources. Almost all of the surface water resources and substantial amount of the groundwater resources are consumed in agriculture and the remaining is used to meet potable and industrial water demand. It is determined that $4.749 \mathrm{hm}^{3}$ water is used for irrigation, $180 \mathrm{hm}^{3}$ water is used as potable water and $67 \mathrm{hm}^{3}$ water is used as industrial water, corresponding to a total of $4.996 \mathrm{hm}^{3}$ water use in the basin. In accordance with this data, $95 \%$ of the water provided to the consumers in the basin is used in irrigation. The amount of water used as potable water and industrial water are $4 \%$ and $1 \%$, respectively.

It is estimated that $4.356 \mathrm{hm}^{3}$ water will be used for irrigation, $400 \mathrm{hm}^{3}$ water will be used as potable water and $142 \mathrm{hm}^{3}$ water will be used as industrial water, corresponding to a total of $4.898 \mathrm{hm}^{3}$ in the basin in 2050. In accordance with this estimation, it is predicted that $89 \%$ of the water provided to the consumer in the future will be used for irrigation, $8 \%$ for potable water and $3 \%$ for industrial water.

The main reasons of the decrease in groundwater table in the last two decades are inability to supply agricultural demand from surface water resources and agricultural practices have not been performed compatible with the water budget of the basin.

Precipitation is not sufficient to recharge groundwater resources and the decrease in groundwater table. Water restrictions would be obvious in the future considering further impacts of climate change in the region, unless an effective basin management plan implemented for the basin.

Water budget deficiencies and decreases in groundwater table are forecasted for the 20152050 period considering trends in population growth, changes in water demand of water-consuming sectors and changes in water potential (surface- and ground-water) according to global climate models. 
The vulnerability of the irrigated-agriculture lands, which is a sub-sector of agricultural sector, is assessed in the light of expected deficiencies in the water budget and decreases in groundwater table. Mean annual decrease of water table is $0.99 \mathrm{~m}$ in Konya Basin (Table 3.1)

Table 3.1.

Decreases in ground water levels in sub-basins of Konya Basin

\begin{tabular}{|c|c|c|c|c|c|c|}
\hline \multirow[b]{2}{*}{ Sub-Basin } & \multirow{2}{*}{$\begin{array}{l}\text { Sub } \\
\text { Basin } \\
\text { No }\end{array}$} & \multirow[b]{2}{*}{ Well No } & \multirow{2}{*}{$\begin{array}{l}\text { Name of the } \\
\text { Well }\end{array}$} & \multirow{2}{*}{$\begin{array}{l}\text { \# of years } \\
\text { measured }\end{array}$} & \multicolumn{2}{|l|}{ Decrease } \\
\hline & & & & & Total (m) & $\begin{array}{l}\text { Average } \\
\text { (m/year) }\end{array}$ \\
\hline \multirow{2}{*}{ Beyşehir (16/1) } & $16 / 1-a$ & 52770 & Doğanbey & 3 & 5.20 & 1.73 \\
\hline & $16 / 1-b$ & 49340 & Taşağıl & 3 & 1.79 & 0.60 \\
\hline \multirow{6}{*}{$\begin{array}{l}\text { Konya-Çumra- } \\
\text { Karaman }(16 / 2)\end{array}$} & $16 / 2-a$ & 8185 & Hatip & 34 & 39.00 & 1.15 \\
\hline & $16 / 2-c$ & 181 & Fethiye & 19 & 16.50 & 0.87 \\
\hline & $16 / 2-c$ & 52267 & Arıkören & 19 & 22.00 & 1.58 \\
\hline & $16 / 2-c$ & 9431 & A.Hüyüğü & 28 & 14.10 & 0.50 \\
\hline & $16 / 2-d$ & 52268 & Eğilmez & 31 & 37.40 & 1.21 \\
\hline & $16 / 2-d$ & 52258 & Gülfet Yayla & 39 & 31.60 & 0.81 \\
\hline \multirow{5}{*}{$\begin{array}{l}\text { Karaman-Ayranc1- } \\
\text { Akçaşehir } \\
(16 / 3)\end{array}$} & $16 / 3-a$ & 30642 & Erentepe & 15 & 13.00 & 0.87 \\
\hline & $16 / 3-a$ & 28719 & Güneysınır & 15 & 23.30 & 1.55 \\
\hline & $16 / 3-b$ & 20122 & Sudurağ 1 & 16 & 39.00 & 2.44 \\
\hline & $16 / 3-c$ & 30270 & Höyükburun & 12 & 17.00 & 1.42 \\
\hline & $16 / 3-c$ & 13314 & Akçaşehir & 29 & 31.00 & 1.07 \\
\hline \multirow{2}{*}{ Ereğli-Bor (16/4) } & $16 / 4-b$ & 52259 & Yeniköy & 13 & 14.00 & 1.08 \\
\hline & $16 / 4-b$ & 9749/A & Y. Zengen & 13 & 2.00 & 0.15 \\
\hline \multirow{3}{*}{$\begin{array}{l}\text { Sultanhanı }(16 / 5) \\
\text { Altınekin }\end{array}$} & $16 / 5-b$ & 52266 & Eşmekaya & 16 & 17.20 & 1.07 \\
\hline & $16 / 6$ & 221 & Tutup & 40 & 22.20 & 0.56 \\
\hline & $16 / 6$ & 46392 & Meydan & 13 & 17.55 & 1.35 \\
\hline \multirow{3}{*}{$\begin{array}{l}\text { Cihanbeyli- } \\
\text { Yeniceoba-Kulu } \\
(16 / 7)\end{array}$} & $16 / 7-a$ & 53704 & Siğırcık & 8 & 4.55 & 0.57 \\
\hline & $16 / 7-a$ & 53706 & K. Kartal & 8 & 2.00 & 0.25 \\
\hline & $16 / 7-c$ & 53707 & Kulu & 5 & 5.00 & 1.00 \\
\hline Average & & & & $\mid 18$ & 16.79 & 0.99 \\
\hline
\end{tabular}

The potable water sector constitutes less than $5 \%$ of the total water need of Konya Basin, however it is vital for human life. The potable - use water sector is used for meeting the needs of public and households, commercial, public institutions, schools, hospitals, charity institutions and some small - medium scaled industrial facilities.

$95 \%$ of the water use in the basin is currently being used by the agriculture sector. It is calculated that this value will decrease and become $85 \%$ in the future. Since the water resources are limited, the vulnerability of potable and use water sector to drought conditions is directly proportional with the water need of the agriculture sector. 


\section{Konya Basin Drought Management Plan}

In order to mitigate and/ or eliminate the negative impacts of drought and water scarcity on the production resources and socio-economic life, to ensure the sharing of water among sectors under drought conditions, and to ensure the rational and sustainable use of limited water resources, the economic, sustainable and technically applicable measures that will be applied in Konya Basin and the contribution provided by each measure to the target of mitigating the impacts of drought and water scarcity are determined, assessed and put in a rank of priority.

Care is paid to ensure that the measures proposed within the scope of this report are compliant with "Strategy and Action Plan for Combating Agricultural Drought (2013-2017)" document prepared under the coordination of Ministry of Food, Agriculture and Livestock (MFAL). Furthermore, the policies, strategies and actions indicated in the "Tenth Development Plan (2014-2018)" and "Regional Development National Strategy (2014-2023)" prepared under the coordination of Ministry of Development, the "KOP Action Plan (2014-2018)" prepared by Konya Plain Regional Development Administration; the "Strategic Plan of Ministry of Food, Agriculture and Livestock (2013-2017)"; the targets for 2023 determined by the Ministry of Forestry and Water Affairs, "2013-2017 Strategic Plan" and "DSİ Strategic Plan (2015-2019)" are taken into consideration.

While determining the measures, matters such as the impact of climate change on the moderate, severe and extreme drought risks of the basin, the probable droughts in the future, the future water budget, the way in which all water-using sectors will be impacted (municipal, agriculture, industry and ecosystem) are taken into consideration in addition to the planned irrigation investments and agricultural policies. Furthermore, national and international references (action plans, strategy documents, academic publications, projects) are examined and new methods that can be applied in Konya Basin are included in the scope.

In Konya Basin Drought Management Plan, the agencies responsible for the application of the measures and partner agencies, which can be cooperated during the application of the measures are identified with detailed information about the determined measures. The measures are grouped under eight main goals of drought mitigation:

1. Improve Water Availability Monitoring and Drought Impact Assessment

2. Increase Public Awareness and Education

3. Enhance Mechanisms to Provide Water Supplies to Sub-basins That Are Under Risk of Water Shortage During Droughts

4. Coordinate and Provide Technical Assistance for Planning Efforts for Development of Water and Soil Resources by Local Administrations, General and Regional Directorates of Ministries

5. Reduce Water Demand, Encourage Water Use Efficiency and Conservation of Water Resources and Water Quality 
6. Reduce Drought Impacts on Konya Basin's Economy, People and Ecosystem

7. Develop Interagency Stakeholder Coordination

8. Evaluate Potential Impacts from Climate Change

\section{Discussion and Conclusion}

Konya Basin is the driest hence the most vulnerable area of Turkey against droughts. The water potential of the basin fails to meet the water consumption, so water transfer projects like "Mavi Tunnel" have already been carried out. Such projects are also aimed at reducing the pressure on groundwater. In this basin, tremendous amount of agricultural activities are being conducted and $95 \%$ of the water provided to the consumers in the basin is used in agricultural irrigation. In this study, annual utilizable water potential was calculated as $3870 \mathrm{hm}^{3}$ where the annual consumption is $4996 \mathrm{hm}^{3}$. Thus, groundwater table of the basin is decreasing around one meter per year.

In drought periods, due to lack of sufficient water resources, Konya Basin is expected to experience further difficulties and faster decreasing of the groundwater table. In order to mitigate the risk of potential droughts, a Drought Management Plan for this basin was prepared.

In this study, necessary measures are identified for pre-drought, post-drought and during drought stages to provide an efficient drought mitigation at Konya Basin considering prospective drought risks. Implementation of these measures which were defined by considering water budget of the basin and drought vulnerability will increase drought resistance and decrease drought related losses.

A series of scientific studies were conducted in order to define the measures which includes evaluation of drought characteristics and water potential of Konya Basin. Climate studies were conducted to estimate future climatological conditions of the basin which may occur as a result of global climate change. Climate studies were conducted using different global circulation models and different scenarios. Drought analyses were made by using both the current conditions and the estimated future conditions of the climate. Sectorial vulnerability assessment was made by evaluating water budget of the basin by using current and the potential future water demand of different type of water users and sectors.

All of these works are essential to estimate the damage of future droughts on different parties which is also essential to establish a proper drought management mechanism and define proper measures against prospective drought risks. Measures are defined by considering the capacities of the related institutions and for each measure responsible institutions were clearly indicated.

However, all of the measures defined in this study are based on current data and some projections which may not include potential unanticipated changes. In order to include unanticipated changes in climatology and socio-economy in the basin, drought management plans have to be revised on certain periods especially after drought events. 


\section{References}

DSI (2012). 2013 Investment Program and Budget Presentations Report. Konya: DSI 4th Regional Directorate.

IPCC (2014). The Physical Science Basis Contribution of Working Group I to the Fifth Assessment Report of the Intergovernmental Panel on Climate Change. Cambridge, England and New York, USA: Cambridge University Press.

Okkan, U., and G. Inan. (2014). Bayesian learning and relevance vector machines approach for downscaling of monthly precipitation. ASCE Journal of Hydrologic Engineering.

OSİB (2012). National Watershed Management Strategy 2012-2023. Ankara: Information Technology Department.

SYGM (2015), Konya Basin Drought Management Plan. Ankara: General Directorate of Water Management

Tripathi, S., V.V. Srinivas, and R.S. Nanjundiah. (2006) Downscaling of precipitation for climate change scenarios: a support vector machine approach. Journal of Hydrology (330), 621-640.

Türkeş, M. (1990). Palmer Kuraklık İndisi'ne Göre İç Anadolu Bölgesi'nin Konya Bölümü’ndeki Kurak Dönemler ve Kuraklık Şiddeti. Coğrafi Bilimler Dergisi, 129-144.

UNCCD. (1994). The United Nations Convention to Combat Desertification.

Wilby, R.L., C.W. Dawson, and E.M. Barrow (2002). "SDSM - a decision support tool for the assessment of climate change impacts." Environmental Modeling \& Software 17: 147-159.

Wilhite, D., \& Glantz, M. (1985). Understanding the drought phenomenon: the role of definitions. Water International (10), 111-120.

WWF. (2008). Drought Assessment Report. World Wild Foundation.

Yağc1, B. (2007). Climate Change and Drought Analysis.Turkish State Meteorological Services. 


\section{Extended Turkish Abstract (Genişletilmiş Türkçe Özet)}

\section{Kapsamlı Bir Kuraklık Yönetim Planı Oluşturulması İçin Gerekli Araçlar - Konya Havzası Çalışması}

Kuraklık doğal (iklimsel) süreçler sonucu oluşarak belirli zaman aralıkları için belirli bölgeleri etkisi altına alabilir. Taşkın ve deprem gibi doğal bir afet olan kuraklık bu afetlerden farklı olarak çok uzun bir oluşma ve etkileme süresine sahiptir. Belirgin bir kuraklık olayının etki süresi yıllarla ifade edilebilir. Kuraklığın gelişmesi uzun yıllar alsa da doğurduğu sonuçlar ciddi ve maliyetli olmaktadır. Kuraklığın etkisini gösterdiği dönemde ve sonrasında oluşturacağı etkilerin azaltılabilmesi için etki ettiği bölgenin kuraklık hassasiyetinin en iyi şekilde tanımlanması gerekmektedir.

Birleşmiş Milletler Çölleşme ile Mücadele Sözleşmesinde belirtilen tanıma göre kuraklık, yağışların kaydedilen normal düzeylerin önemli ölçüde altına düşmesi sonucu arazi ve kaynak üretim sistemlerini olumsuz olarak etkileyen ve ciddi hidrolojik dengesizliklere yol açan doğal olaydır (UNCCD,1994). Kuraklık, su kaynaklarının kısıtlı olduğu kurak ve yarı kurak alanlarda ve özellikle kapalı havzalarda çok önemli bir sorun haline gelmiştir.

Ülkemizin 25 havzasından biri olan Konya Havzası kapalı bir havza özelliği taşımakta ve Türkiye’nin kuraklık riskinin en yoğun olarak yaşandığı alanlarının başında gelmektedir. Konya Havzasının üretim kaynakları, sosyo-ekonomisi ve ekosistemi uzun süreli kuraklık koşullarına karşı hassas olup kuraklık etkileri, kuraklığın nerede meydana geldiğine bağlı olarak değişiklik göstermektedir. Havzada kuraklık koşullarının erken tespiti ve etkili müdahalesi azami derecede gerekli ve önemlidir.Muhtemel kuraklık risklerinin olumsuz etkilerinin azaltılması ve kuraklık problemlerinin çözümüne yönelik olarak Konya Havzası için kuraklık yönetim planı hazırlanmıştır. Kuraklık Yönetim Planının maksadı, havza sınırları içerisinde yaşanabilecek farklı şiddetlerdeki kuraklık koşullarında kısa veya uzun vadeli olumsuz etkileri azaltmak için etkili ve sistematik bir çerçeve oluşturmaktadır.

Bu çalışmada söz konusu yönetim planının hazırlanması sürecinde elde edilen tecrübelerin paylaşılması ve kapsamlı bir kuraklık yönetim planı oluşturulması için gerekli araçların tartışılması amaçlanmıştır. Kuraklık yönetim planlarının hazırlanması, kuraklık risklerinin tespiti, iklim değişikliği analizleri, su bütçesinin ve su bütçesinde meydana gelebilecek değişimlerin tespiti, sektörel etkilenebilirlik analizi ile kuraklık öncesi, sonrası ve esnasında alınacak önlemlerin yer aldığı kuraklık yönetim planının hazırlanması aşamalarından oluşmaktadır.

İlk olarak küresel iklim değişikliğinin gelecekte Konya Havzasında oluşturması muhtemel etkilerinin tespiti için iklim modellemesi çalışmaları gerçekleştirilmiştir. Gelecek dönemde havza genelinde yağışların azalacağı ve sıcaklıkların artacağı öngörülmektedir. Bu değişimlerin havzada gelecek dönemde yaşanması muhtemel kuraklıkların karakteristiklerini ne şekilde değiştireceğinin tespit edilmesi için de kuraklık risk analizleri gerçekleştirilmiştir. Kuraklık risklerinin tespiti için, uluslararası literatürde kabul görmüş farklı kuraklık indisleri kullanılmıştır. Karmaşık bir süreç olan kuraklığg belirlemek ve nitelendirmek için, çok sayıda klimatolojik, meteorolojik ya da hidrolojik indikatör ve indis kullanılmaktadır. Kuraklık indisleri, kurak koşulların ortaya çıkışını ve gelişimini çok açık bir biçimde tanımlayabilmektedir. Bu sayede 
havzada geçmiş dönemde yaşanmış kuraklıklar ölçüm istasyonlarından temin edilen tarihsel veriler, gelecek dönemde yaşanması muhtemel kuraklıklar da iklim modellerinin sonuçları dikkate alınarak tespit edilmiştir. Gelecek dönemde yaşanacak kuraklıkların daha şiddetli ve daha uzun süreli olacağı, özellikle 2035-2040 yılları arasında havzada ciddi kuraklıklar yaşanabileceği model sonuçlarında görülmektedir.

Kuraklık nedeniyle yağış ve sıcaklık değişimlerinden en çok etkilenecek hidrolojik süreçlerin başında akarsu akımları gelmektedir. Bu nedenle kuraklığın havzaların su potansiyellerinde önemli değişimlere neden olması beklenen bir sonuçtur. Havza su potansiyellerinin değişmesi ise özellikle bu havzalarda yer alan içme suyu, sulama ve enerji amaçı baraj haznelerinin arz sürekliliklerinde önemli sıkıntılar ortaya çıkaracaktır. Geçmiş yıllarda, farklı akım koşulları altındaki gözlemlere dayalı olarak planlanan ve inşa edilen bu barajlar, iklim değişikliği nedeniyle değişen yeni akım koşullarında, planlandıkları esaslar dâhilinde işletilemeyecek, planlanan arz değerlerine ulaşamayacaklardır. Bu nedenle, kuraklığın neden olacağı değişimlerin önceden kestirilip, su potansiyellerindeki belirsizliğin açıklanması büyük önem taşımaktadır. Bu çalışmada üç farklı küresel iklim modeli çıktıları kullanılarak dinamik ve istatistik ölçek indirgeme yöntemleri kullanılarak bölgesel analiz gerçekleştirilmiş; elde edilen hidrometeorolojik parametrelerdeki değişimlerin akımlar üzerindeki etkileri ise yağış-akış modelleriyle irdelenmiştir. Su bütçesi modelleri (HEC-HMS, Thronthwaite Monthly Water Balance Model) son 40 yıllık yağış, sıcaklık ve akış verileriyle kalibre edilerek model parametreleri belirlenmiştir. Kalibre edilen model, 2015-2020 yılları arası dönem için yıllık, 2020-2050 yılları arası dönem için 5 yıllık periyotlarla aylık ve mevsimlik zaman ölçeğinde yaratılan yağış ve sıcaklık verileriyle çalıştırılarak gelecekteki akımlar hesaplanmıştır. Yapılan çalışmalar sonucunda ortaya çıkan veriler ışı̆̆ında havzada yüzeysuyu ve yeraltısuyu kaynaklarının mevcut durumu ve projekte edilen dönemler için su bütçesi hesaplanmıştır. Havza'nın toplam yeraltı ve yerüstü su potansiyeli 1974-2013 periyodunda düşen yıllık ortalama toplam yağış değeri dikkate alınarak hesaplanmıştır. Bu çalışmada, yıllık kullanılabilir su potansiyeli $3870 \mathrm{hm}^{3}$, yıllık kullanım ise $4996 \mathrm{hm}^{3}$ olarak hesaplanmışır. Bu durum havza yeraltı suyunun her yıl ortalama $1 \mathrm{~m}$ aşağı çekilmesine yol açmaktadır.

Konya Havzasında tüketiciye sunulan suyun \%95'i tarımsal amaçlı olarak kullanılmaktadır. Toplam tarımsal su ihtiyacının \%68'i $\left(3.227 \mathrm{hm}^{3}\right)$ yeraltısuyu kaynaklarından, \%32'si $\left(1.521 \mathrm{hm}^{3}\right)$ yüzeysel su kaynaklarından karşılanmakta; 635.221 ha alan yeraltısuyu ve 295.285 ha alan yüzeysel su kaynakları ile sulanmaktadır. Su kaynaklarının kısıtlı olması sebebiyle içme ve kullanma suyu ve sanayi sektörlerinin kuraklık koşullarından etkilenebilirliği tarım sektörünün su ihtiyacı ve tarımsal sulamaya ayrılacak su miktarı ile doğru orantılı olacaktır.Belirtilen tüm bilimsel gerçekler ışığında, Konya Havzasında muhtemel kuraklık riskleriyle karşılaşıldığında yaşanacak olan olumsuz etkilerin azaltılması ve kuraklık problemlerinin çözümüne yönelik olarak kuraklık öncesinde, esnasında ve sonrasında alınacak tedbirler belirlenmiştir. Tedbirlerin uygulanmasından sorumlu kurum/kuruluş ile tedbirlerin uygulanması sırasında işbirliği yapılabilecek yardımcı kurum/kuruluşlar ile tedbirlerin havzanın kuraklık hassasiyeti göz önüne alınarak belirlenen öncelik durumu kuraklık yönetim planında belirtilmiştir.

Mevcut durumda havzaya ait olan veriler ve bu veriler üzerinden gerçekleştirilen projeksiyonlar kuraklık yönetim planında yer almaktadır. Havza koşullarında meydana gelebilecek beklenmedik değişimlerin (sektörel değişimler, ciddi kuraklık olayları vb.) hesaba katılabilmesi için kuraklık yönetim planının belirli periyotlarla, güncellenmesi gereklidir. 